\title{
Combinations of Conditions for Network Effectiveness: A Fuzzy- Set Qualitative Comparative Analysis of 37 International Development Intervention Cases
}

\author{
Seungheon $\operatorname{Han}^{1} \cdot \operatorname{Minah}_{\mathrm{Kang}^{2}}$ (D)
}

Accepted: 28 April 2021/Published online: 2 June 2021

(C) International Society for Third-Sector Research 2021

\begin{abstract}
Most international development projects that aim to eradicate poverty and improve the quality of life of people in low- and middle-income countries are implemented through a collaborative network of multiple parties, including non-governmental organizations (NGOs). However, how network effectiveness in international development projects can be achieved remains unclear. Using fuzzy-set qualitative comparative analysis, this study explores the causal conditions of network effectiveness of 37 international development projects implemented by South Korean NGOs based on a theoretical lens of collaborative networks. Findings revealed two causal configurations for network effectiveness. Even under a lack of network management capacity and unintegrated networks, or under resource deficiency and lack of network management capacity, high-level local capacity or high-quality collaboration among partners was shown to produce network effectiveness. An in-depth analysis of two cases with successful network effectiveness was also conducted to achieve a more thorough and comprehensive understanding of the causal conditions. The findings suggest practical solutions to manage collaborative networks and compensate for deficiencies of diverse conditions to improve network effectiveness.
\end{abstract}

Keywords Collaborative networks · Non-governmental organizations (NGOs) - International development cooperation - Fuzzy-set qualitative comparative analysis (fs/QCA)

Minah Kang

minahkang@ewha.ac.kr

1 Korea Institute of Public Administration, Seoul, Republic of Korea

2 Ewha Womans University, Seoul, Republic of Korea

\section{Introduction}

Collaborative networks, a sphere for collaboration formed across governmental, private, and non-governmental organizations (NGOs), have been suggested as an effective mechanism to resolve the public challenges that cannot be solved by a single entity (Agranoff \& McGuire, 2004; Bryson et al., 2006). Similar to general public services, most international development interventions, which aim to resolve problems related to poverty and to finally improve the quality of life of people in low- and middle-income countries (LMICs), are also implemented through a collaborative network formed by diverse participants.

In the field of international development, discussion on a collaborative network has been emphasized in relation to aid effectiveness. Throughout the course of the High Level Fora on Aid Effectiveness, which began in 2003 in Rome and were last held in 2011 in Busan, international discussion to overcome so-called aid fatigue has focused on finding practical solutions to improve aid effectiveness (Barnes \& Brown, 2011; OECD/DAC, 1996, 2010). In the Millennium Development Goals (MDGs), "the idea of partnership" began to be explicitly treated as "the key normative concept" in Goal Eight (Barnes \& Brown, 2011: 166). Recently, the sustainable development goals (SDGs) treated partnership more importantly through an emphasis on encompassing more diverse entities, including the private sector, particularly in pluralized development finances and private sector-led development (Mawdsley, 2017).

While the partnership seems to have been conceptually and practically established as a global normative principle, one criticism has concerned the lack of a clear philosophical consensus on what partnership means and how it should be formed to be effective (Barnes \& Brown, 2011). Moreover, the partnership is often used as a tool for 
expanding the political and economic powers of both traditional and non-traditional donors into recipient countries (Abdenur \& Marcondes-Neto, 2014; Mawdsley, 2017). In addition to this global partnership, the collaboration is highly susceptible to failure at any time since conflicts inevitably arise in the process of inter-sectoral or interorganizational collaboration (O'Leary \& Bingham, 2007). Despite these risks and limitations, we are often faced with a "paradox" that forces us to work together to solve public wicked problems (O’Leary \& Bingham, 2007: 6), including global poverty.

Collaboration in international development has emerged in various forms and at different levels, from cross-national efforts such as coordination of international aid rules and principles among donors and recipient countries, led by international organizations such as the Organization for Economic Co-operation and Development's Development Assistance Committee (OECD/DAC) or World Health Organization (WHO), to national or sectoral practices such as South-South cooperation (Marcondes-Neto, 2014; Mawdsley, 2017) and public-private partnerships (PPPs). Noting that relationships between participants in most international development projects are a "complex web" of donors, implementers, and beneficiaries in both developed and developing countries (Diallo \& Thuillier, 2005; Khang \& Moe, 2008; Youker, 1999), scholars and practitioners contend that successful project implementation is not possible without effective management strategies for collaborative networks (Bano, 2011, 2018; Brinkerhoff, 2003; Haque, 2004; Kamya et al., 2017; Pfeiffer, 2003; Shin et al., 2017).

However, the understanding of how collaborative networks in the context of international development produce intended effectiveness remains limited. Despite the collaborative networks for international development formed by diverse entities - such as funders, beneficiary groups, or local entities-prior studies tend to understand collaboration mostly as a type of public and private partnership (PPP) (Ameyaw \& Chan, 2013; Chataway \& Smith, 2006; Poulton \& Macartney, 2012; Thorpe, 2018). This is because PPP has been considered one of the most powerful collaboration mechanisms for effectively leading desired development outcomes, despite criticism on its contract process and effectiveness (Abdullah \& Khadaroo, 2020; Miraftab, 2004). With regard to collaboration in the arena of international development, there has been some discussion in terms of aid coordination and fragmentation issues from the donor side (Bigsten \& Tengstam, 2015). However, there has been limited understanding of the diverse aspects of collaboration in the implementation process of international development interventions.

Additionally, prior studies tend to assume a linear relationship between development outcomes and its diverse antecedent factors (Ika et al., 2012; Shin et al., 2017). For example, Shin et al. (2017) explored explanatory factors for project performance led by the World Bank focusing on the partnership between government and non-government agencies. Comparing with earlier research that mainly explored macro-level factors such as level of democratic status, economic development, or good governance (Grindle, 2004; Holmberg \& Rothstein, 2011; McGuire, 2010) as well as project management (Cleland \& King, 1975; Khang \& Moe, 2008; Muriithi \& Crawford, 2003; Pinto \& Slevin, 1989; Struyk, 2007; White \& Fortune, 2002), findings from Shin et al. (2017) contributed to an understanding on how and whether collaboration factors have influences on development outcomes. However, these studies did not consider the conjoint effect of diverse variables that affect development outcomes achieved by collaborative networks.

This study aims to explore the configurations of causal conditions to lead network effectiveness in cases of international development projects implemented by NGOs of South Korea. We applied the fuzzy-set qualitative comparative analysis (fs/QCA) since it is a useful method for analyzing middle- $\mathrm{N}$ cases and the combinational effect of multiple attributes that may jointly affect outcomes. Due to its strengths, this method has been applied in various fields, including public management (Cristofoli et al., 2019; Raab et al., 2013; Wang, 2016). After analysis of the fs/QCA, we selected two cases and conducted in-depth interviews with project managers to explore the mechanisms by which network effectiveness was achieved. As one of the distinctive strengths of the fs/QCA method, researchers can explore the cases that are included in the set of configurations for interpreting the analytic results of configurations (Lee, 2014). The mixed-method approach allowed us not only to expand our understanding of how the attributes of collaborative networks combined with the project's managerial and environmental factors but also to have an indepth contextual understanding of the analytic results.

\section{Theoretical Framework}

\section{Literature Review}

Network Effectiveness: Conceptualization and Definition

Network effectiveness refers to the effects produced by a collaborative network and is usually defined as follows:

the effects, outcome, impacts and benefits that are produced by the network as a whole and that can accrue to more than just the single member organizations in terms of increasing efficiency, client 
satisfaction, increased legitimacy, resource acquisition, and reduced costs (Turrini et al., 2010: 529).

Still, there is a long-standing debate on how network effectiveness can be defined and measured. Because networks are formed by multiple stakeholders with various perspectives, network effectiveness cannot be simply measured by a result-oriented outcome such as a hierarchical organization that has a narrowly defined effectiveness (McGuire \& Silvia, 2009; Provan \& Milward, 2001).

It is notable that a number of scholars focused on community-level network effectiveness of collaborative networks in the public sector that primarily aimed to increase the quality of life of community members (Provan \& Milward, 2001; Raab et al., 2013; Wang, 2016), such as building social capital or the well-being of clients. Similarly, Wang (2016) proposed the quality of life of community residents who served by neighborhood governance networks in Beijing as criteria for network effectiveness. Further, Raab et al. (2013) applied a reduction of recidivism in a community of the Netherlands referring to changes in the incidence of a problem as network effectiveness.

Likewise, in the field of international development and cooperation, effectiveness of interventions to improve the quality of life in the community members has been measured and evaluated using the five criteria suggested by the OECD/DAC (1992): relevance, effectiveness, efficiency, impact, and sustainability. Relevance refers to the appropriateness to the purpose of the development strategies of the country or local area where the project is implemented and beneficiaries' needs are considered. Effectiveness refers to the extent to which the project achieved its goals. Efficiency refers to project budgets and personnel that were used efficiently to generate a better performance. Impact refers to positive or negative changes produced by the projects in the long term, intentionally or unintentionally, directly or indirectly. Lastly, sustainability refers to sustaining benefits to beneficiaries supported by political, financial, environmental, and institutional capacities.

\section{Causal Conditions of Network Effectiveness}

In a search for causal conditions of effectiveness, a number of factors were examined in prior studies on network effectiveness (Alexander, 2012; Chen, 2008; Graddy \& Chen, 2006; McGuire \& Silvia, 2009; Milward et al., 2009; Provan \& Milward, 1995; Raab et al., 2013; Ring \& Van de Ven, 1994; Silvia, 2017; Thomson, 2002; Wang, 2016). Among those, the following factors are notable.

Network Integration A collaborative network covers various aspects of collaboration, conceptualizing and measuring both the structure and process of collaboration (Silvia, 2017). The structure refers to a fixed form or structure comprising more than two nodes or entities (McGuire \& Silvia, 2009; Mischen, 2015; O’Toole, 1997), whereas the process refers to a quality of collaborative procedures by which collaborators formally or informally communicate, share values, and achieve common goals (Bryson et al., 2006; Ostrom, 1990; Thomson, 2002; Wood \& Gray, 1991).

As the structural attributes of a collaborative network improving network effectiveness, network integration usually refers to the extent to which social service providers are interconnected with each other centered on one provider to effectively provide coordinated and integrated services to the people (Morrissey et al., 1994; Provan \& Milward, 1995). Network integration is usually measured by density or degree-centrality, correlated with network effectiveness (Alexander, 2012; Milward et al., 2009; Provan \& Milward, 1995). Studies found that well-integrated networks that are denser or more centralized are more likely to achieve effectiveness (Provan \& Milward, 1995; Raab et al., 2013; Sandström \& Carlsson, 2008; Schalk et al., 2010). While previous studies did not clarify which structural attribute of the network led to greater effectiveness, most empirical tests cited network centrality as a leading condition to effectiveness (Provan \& Milward, 1995; Raab et al., 2013; Schalk et al., 2010; Wang, 2016). For example, centralized networks demonstrated greater effectiveness in delivering mental health services (Provan \& Milward, 1995). Moreover, network activities with higher centrality resulted in higher satisfaction among teachers in the Dutch inter-university network for elementary school teacher training (Schalk et al., 2010). A well-integrated network via a centered agency (actor) in the network can control and coordinate more effectively over the network members' activities than the dense networks with redundant ties and complex linkages among network members. Therefore, the centralized network is assumed to be effective, especially in the service implementation networks in which diverse service providers participated (Provan \& Milward, 1995; Raab et al., 2013).

Quality of Collaboration Studies also showed significant relationships between procedural quality of collaborative networks and its effectiveness (Chen, 2008; Ring and Van de Ven, 1994; Thomson, 2002). Noting that collaboration is an active interaction of participants through a process of collaborative network, Thomson et al. (2009) defined procedural attributes of collaborative networks in terms of three dimensions: governance, organizational autonomy and norms, and showed that these attributes had significant impacts on network effectiveness (Thomson, 2002; Thomson \& Perry, 2006; Thomson et al., 2009). 
In particular, norms-which refer to sharing resources and building trust among collaborative partners in networks-were known to be a major causal condition for improving network effectiveness (Bryson et al., 2006; Chen, 2008; Curnin \& O'Hara, 2019; Graddy \& Chen, 2006; Gulzar \& Henry, 2005; Huxham, 2003; Mondal, 2000; Moynihan, 2005; Waugh, 2003; Willem \& Lucidarme, 2014). For example, willingness to exchange resources and expertise with collaborative partners strengthened partners' motivation to continue the collaboration, thus positively affecting the network effectiveness. Such findings correspond with the resource dependence theory, which contends that collaboration is a useful mechanism by which organizations can acquire resources they do not have (AbouAssi et al., 2016; Bryson et al., 2006; Chen, 2008; O’Toole, 1997; Thomson \& Perry, 2006).

Trust among partners has also been emphasized as a major condition for network effectiveness, because trusting relationships between partners generally reduce unnecessary transaction costs in the process of collaboration and can thus improve network cohesion (Bryson et al., 2006; Chen, 2008; Graddy \& Chen, 2006; Gulzar \& Henry, 2005; Huxham, 2003; Mondal, 2000; Moynihan, 2005; Ostrom, 1990; Waugh, 2003; Willem \& Lucidarme, 2014). However, other studies argued that trusting relationships may not always lead to network effectiveness because of the cumbersome efforts required to build and sustain trust between collaborative partners (Huxham, 2003).

Resource Munificence Resource munificence refers to "the level of resources available to the network from its environment" (Turrini et al., 2010: 540). A number of studies have shown that resource munificence leads to network effectiveness by providing budget or expertise to meet the goals of networks since these resources can stimulate the effective implementation of activities, responsibilities, and collaboration in the networks (Provan \& Milward, 1995; Raab et al., 2013; Wang, 2016). At the same time, contrast arguments remain. For example, studies on project management reported that a large budget of networks may induce network complexity (Martin et al., 2007; Taylor et al., 2012). A large-scale project generally involves many stakeholders, thus making it difficult to effectively communicate and coordinate stakeholders' relationships. However, a large-scale, long-term project with enough financial support and time can go through trials and errors in the implementation process and can thus be improved to produce effective outcomes (Gefen et al., 2016).

Accordingly, resource munificence on network effectiveness may positively affect network effectiveness under certain conditions, such as in the well-integrated network, to address network complexity (Provan \& Milward, 1995; Raab et al., 2013). Raab et al. (2013) have shown that although the resource munificence of the network stimulated each organization to collaborate by providing financial incentives, increased complexity through collaboration among the organizations should be well-managed by the centralized network to achieve network effectiveness.

Network Management Capacity Leadership capacities of network managers were frequently examined as crucial conditions for network effectiveness (McGuire \& Silvia, 2009). In the field of international development, project managers' capacity - in addition to motivation and dedication to the project success or strong management skills for a project budget-has been reported as the most important condition for improving project performance (Khang \& Moe, 2008; Muriithi \& Crawford, 2003; Struyk, 2007; White \& Fortune, 2002). Such capacities include project managers' in-depth understanding of the project that leads to successful outcomes (Khang \& Moe, 2008).

In particular, skillful managers who had extensive experiences related to project management are important to project success (Pinto \& Slevin, 1989; Struyk, 2007; White $\&$ Fortune, 2002). For example, Han (2018) found that while project managers with extensive field experience in international development interventions were appropriately aware of who their core partners were and how they could effectively communicate in collaborative relationships, managers lacking field experiences were not aware of how they could forge relationships with local stakeholders such as government agencies and beneficiaries. Project managers who are dispatched to LMICs are expected to have capacities to conduct international development interventions by collaborating closely with local stakeholders. Extensive field experiences may lead to network effectiveness by coordinating and collaborating with local stakeholders such as local government officials and beneficiaries.

Local Capacity: Resourceful and Committed Local Partners Finally, it is important to find "right collaborative partners" who have appropriate skills and experiences for improving network effectiveness (Graddy \& Chen, 2006; Silvia, 2017). Because collaborative partners share accountability and leadership in a collaborative arrangement, identifying appropriate partners is important to promote network effectiveness (Silvia, 2017). According to Graddy and Chen (2006), there are three motivations to find capable and collaborative partners in communitybased collaborative networks for effective public service delivery: organizational features including size, resource dependency, and collaboration experience; programmatic needs to share resources; and environmental conditions of 
existence of potential partners. For effective international development interventions, programmatic needs to exchange resources are important reasons to have partners. Because most international development projects are implemented in local communities, managers dispatched from donor countries are usually not familiar with local culture, languages, and regional distinct context (Pfeiffer, 2003). For this reason, it is important to collaborate with resourceful and trustworthy local partners, because most dispatched managers should depend on local resources, such as the workforce, to successfully meet the goals of interventions.

\section{Theoretical Framework}

On the basis of a literature review, we developed a theoretical framework of this study in Fig. 1, with network effectiveness as an outcome, and network integration, quality of collaboration, resource munificence, network management capacity, and local capacity are causal conditions. Although we had limited empirical knowledge of multiple conjunctural causal relations among causal conditions, that is, how each causal condition combines to affect outcomes, we assumed that each causal condition is a necessary but not sufficient condition for an outcome. In other words, while network effectiveness is not automatically improved with each causal condition, it could be achieved if each causal condition were present.

\section{Network Effectiveness}

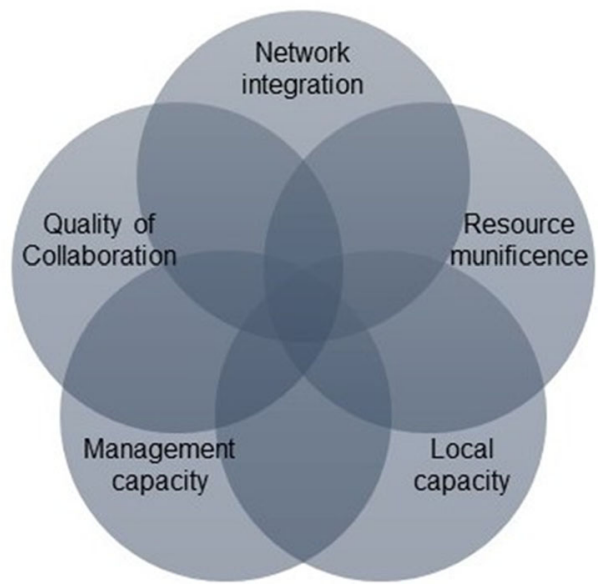

Fig. 1 Theoretical framework

\section{Methods}

\section{Sampling and Data Collection}

NGOs have gained attention as a critical and leading actor of collaborative networks in order to deliver social services (Chen, 2008; Chen \& Graddy, 2010) due to their extensive information and work experiences in delivering services, as well as high accessibility for the local community (Poole, 2008; Sakamoto, 2012). Globally, governmental agencies increasingly contract with NGOs to effectively implement and deliver social and public services to the communities (Chen, 2008; Chen \& Graddy, 2010; Gazley, 2008; Uster et al., 2019).

Similarly, in South Korea, which achieved the highest annual average growth rate of $11.9 \%$ in its official development assistance (ODA) volume among DAC member countries in 2019 (Office for Government Policy Coordination, n/a), ${ }^{1}$ NGOs recently became the most critical implementers of various social services including international development projects due to their strengths of regional accessibility and expertise. In particular, from 2000 to 2016, Korean government agencies contracted out development projects to NGOs, and the contracting volume rapidly increased from about 470,000 dollars to 18 million dollars (Office for Government Policy Coordination, 2016). In the implementing process of the development projects, opportunities for collaboration between NGOs and governmental agencies are increasing and becoming more important in effectively delivering social services to the people.

A management mode of collaborative networks of this study is assumed to be the "lead organization mode" (Milward \& Provan, 2006; Provan \& Kenis, 2008) with an NGO acting as the core implementing agency in our samples. In this study, a NGO forms a collaborative network with local government agencies, beneficiary groups, local staff, contractors, and funding agencies in order to

\footnotetext{
${ }^{1}$ Since becoming a member of the OECD DAC in 2010, South Korea has registered an increase in its ODA volume, with an ODA grant equivalent measure estimated at USD 2.5 billion in 2019. From 2010 to 2018 , it achieved an average annual growth rate of $11.9 \%$ among DAC member countries, whose annual average growth rate was $2.4 \%$. While the proportion of Korean bilateral ODA was $74.2 \%$ in 2018 , the multilateral ODA was $25.8 \%$. Korean ODA has been provided on priority to Asian countries (46.7\% of Korean ODA in 2018) due to their geographical closeness and cultural ties. Recently, African countries have also received significant share of Korean ODA (27.0\% of Korean ODA in 2018). Korean ODA has primarily focused on supporting economic infrastructure and services (40.2\% in 2018), followed by social infrastructure and services (30.3\% in 2018). The Korean government plans to increase investment in health, education, and agricultural sectors as well as in the environment sector in accordance with the SDGs (Office for Government Policy Coordination, $\mathrm{n} / \mathrm{a})$.
} 
conduct a development project in the local community. The NGOs take core roles for managing the whole network, and Fig. 2 illustrates an example on the collaborative network of international development projects.

For our surveys, we selected NGO project managers according to the following inclusion criteria: (1) whether they managed a project in the field for longer than a year, so they would have sufficient understanding of the project's collaborative network, and (2) the project that they managed was a multi-year project that lasted for more than 2 years so that the project was established as a meaningful part of the collaborative network. Based on their extensive experiences and access to the network information, we considered each project manager to be capable of evaluating the network effectiveness (McGuire \& Silvia, 2009).

Among the project managers from 127 NGOs affiliated in the Korea NGO Council for Overseas Development Cooperation (KCOC), the largest alliance of South Korean development NGOs, 42 project managers answered the questionnaires. Because two of these managed two projects each, 44 project cases were collected. Seven of the total managers were excluded because they did not meet the inclusion criteria regarding experience in the field. A final total of 37 project cases were selected for fs/QCA analysis, ranging from 2010 to 2017.

The questionnaire that we used for our survey was originally adapted from Graddy and Chen (2006) and Thomson et al. (2009) and then revised to meet our research objectives. Before finalizing the survey instrument, we pretested the questionnaire using cognitive interviews and expert panels (Czaja, 1998; Hughes, 2004; Presser \& Blair, 1994). The survey was conducted from May 10, 2017, to October 16, 2017.

\section{A Mixed-Methods Approach}

For an in-depth understanding of the context of analytic results, this study applied a mixed-method approach by integrating the fs/QCA method and a qualitative case study.

\section{The Fuzzy-Set Qualitative Comparative Analysis}

This study used a fs/QCA method (Ragin, 1987, 2000). The most distinctive feature differentiating fs/QCA from standard multivariate regression analysis is that it examines a set relation by focusing on interaction effects among independent variables (causal conditions). Whereas multivariate analysis focuses on the variables that independently affect dependent variables and is interested in the net effect of critical variables on the outcomes, fs/QCA focuses on the causal complexity (Lee \& Lee, 2017; Ragin, 2000) and explores multiple causal paths that lead to the same outcome (Grofman \& Schneider, 2009; Schneider \& Wagemann, 2010).

Despite its strengths, a known limitation of fs/QCA is the "limited diversity" problem (Schneider \& Wagemann, 2012). In fs/QCA, if too many conditions are set, the total number of combinations may exceed the number of causal conditions. In such cases, it is confusing to understand and interpret the results of analysis (Schneider \& Wagemann, 2007). Therefore, we selected key variables for causal conditions and outcomes based on past studies in the public management and international development sectors.

Two methodological indicators of the analysis modelconsistency and coverage-were calculated to evaluate fs/ QCA models. For statistical significance, the relationship between the causal conditions and outcome was considered empirically valid if the consistency score approached 1.0, and it was greater than 0.75 (Lee \& Lee, 2017; Ragin, 2006). If the consistency of each case was over 0.75 , the causal condition was coded 1 ; if not, it was coded 0 . The coverage indicator measures the number of cases that are included in a particular causal combination, indicating the importance of a conditional combination, similarly to statistical strength in multivariate regression analyses (Lee \& Lee, 2017; Ragin, 2006). Coverage score was recommended to be greater than 0.3 (Lee \& Lee, 2017; Ragin, 2006).

In fs/QCA analysis, among the three options of solutions (i.e., complex, parsimonious, and intermediate), we choose the intermediate solution because it is most interpretable (Lee \& Lee, 2017; Ragin, 2008). The fs/QCA method uses three Boolean operators: The Boolean not operator refers to a low membership score for the specific condition variable. The Boolean addition, denoted by "+", means the logical operator "or"; Boolean multiplication, denoted by "*”, means the logical operator "and".

\section{Case Study}

One of the distinctive strengths of the fs/QCA method is that the method allows researchers a deeper exploration and interpretation of the analytic results using cases that are included in the configuration sets (Lee, 2014). To explore the context and characteristics of configuration sets, we conducted a case study through in-depth interviews with the project managers of one case included in each configuration set. Among the 15 cases representing each configuration set, we selected two cases based on the availability of the project managers for interviews.

\section{Measurement of Outcome and Causal Conditions}

In this study, we chose network effectiveness as an outcome and five causal conditions leading to network 
Fig. 2 Mode of lead organization network adapted from Graddy and Chen (2006) and revised by the researcher

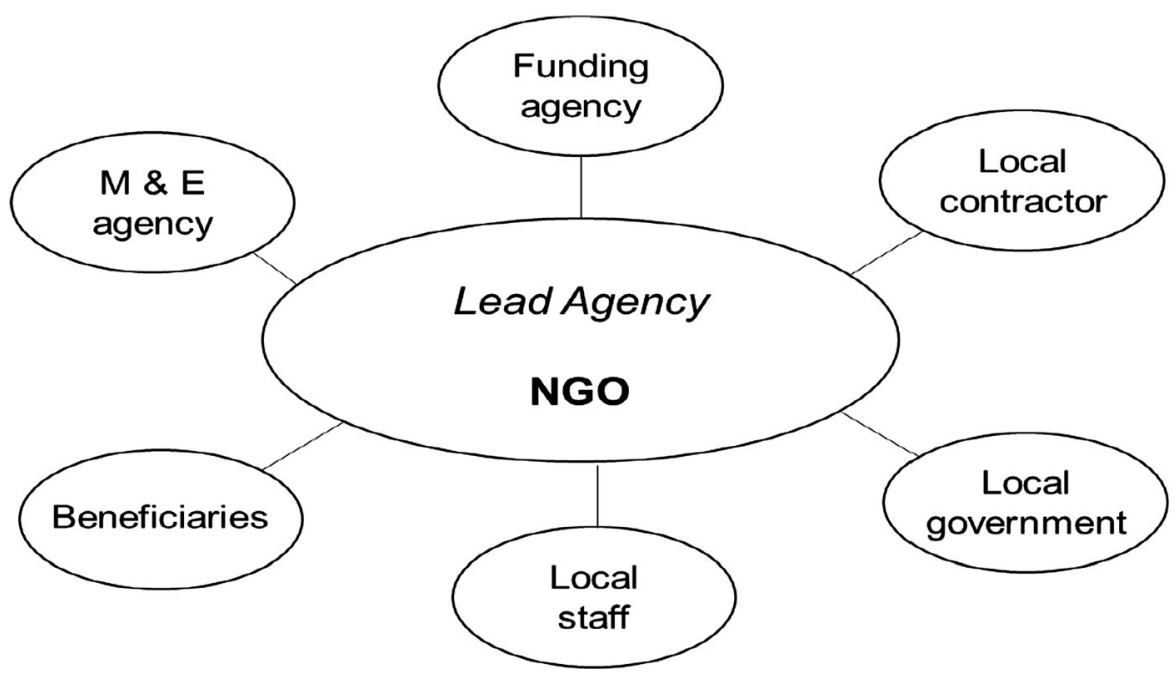

effectiveness: network integration, quality of collaboration, resource munificence, network management capacity, and local capacity (Table 1).
Network effectiveness ("O"), the outcome, was defined as attainment of goals in terms of relevance, effectiveness, efficiency, and sustainability. Relevance was measured by two sub-indicators: relevance to the purpose of the
Table 1 Measurement of outcome and causal conditions

\begin{tabular}{|c|c|c|c|}
\hline & Definition & $\begin{array}{l}\text { Likert } \\
\text { scale }\end{array}$ & Survey questions \\
\hline \multicolumn{4}{|l|}{ Outcome } \\
\hline $\begin{array}{l}\text { Network } \\
\text { effectiveness }\end{array}$ & $\begin{array}{l}\text { Attainment of goals in terms of } \\
\text { relevance, effectiveness, efficiency, } \\
\text { and sustainability }\end{array}$ & & \\
\hline Relevance & $\begin{array}{l}\text { Relevance to the purpose of the } \\
\text { development strategies of the local } \\
\text { area where the project was } \\
\text { implemented and relevance to } \\
\text { beneficiaries' development needs }\end{array}$ & $1-7$ & $\begin{array}{l}\text { How much was your project relevant } \\
\text { to the purpose of the local } \\
\text { development strategy? } \\
\text { How much was your project relevant } \\
\text { to the beneficiaries' development } \\
\text { needs? }\end{array}$ \\
\hline Effectiveness & $\begin{array}{l}\text { The extent to which the project } \\
\text { achieved its goals }\end{array}$ & $1-7$ & $\begin{array}{l}\text { To what extent have you achieved the } \\
\text { goals of your project? }\end{array}$ \\
\hline Efficiency & $\begin{array}{l}\text { The extent to which project budgets } \\
\text { and workforce were efficiently used } \\
\text { to generate better performance }\end{array}$ & $1-7$ & $\begin{array}{l}\text { To what extent have you used the } \\
\text { project budgets and workforce } \\
\text { efficiently for better performance? }\end{array}$ \\
\hline Sustainability & $\begin{array}{l}\text { Sustainability of interest in the project } \\
\text { and support from local governments } \\
\text { and policymakers, sustainability of } \\
\text { budget and local workforce support } \\
\text { from the local community, } \\
\text { sustainability of plans to manage } \\
\text { infrastructure or equipment provided } \\
\text { to locals, and sustainability of well- } \\
\text { trained local workforce after the exit } \\
\text { of the project implementers }\end{array}$ & $1-7$ & $\begin{array}{l}\text { To what extent have the local } \\
\text { government agencies and } \\
\text { policymakers supported the project's } \\
\text { sustainability in the future? } \\
\text { To what extent are the local budget } \\
\text { and workforce sustainable in the } \\
\text { future? } \\
\text { To what extent were the provided } \\
\text { infrastructure and equipment } \\
\text { managed well under local } \\
\text { supervision? } \\
\text { To what extent was a well-trained } \\
\text { local workforce enough to sustain } \\
\text { the project after the end of the } \\
\text { project? }\end{array}$ \\
\hline
\end{tabular}


Table 1 continued

\begin{tabular}{|c|c|c|c|}
\hline Causal conditi & Definition & $\begin{array}{l}\text { Likert } \\
\text { scale }\end{array}$ & Survey questions \\
\hline $\begin{array}{l}\text { Network } \\
\text { integration }\end{array}$ & Network centrality & $1-8$ & $\begin{array}{l}\text { How often has your organization } \\
\text { communicated with your partners? }\end{array}$ \\
\hline $\begin{array}{l}\text { Quality of } \\
\text { Collaboration }\end{array}$ & $\begin{array}{l}\text { Norms among partners in the network } \\
\text { including the degree of resource } \\
\text { sharing and the level of trust-building. }\end{array}$ & & \\
\hline $\begin{array}{l}\text { Resource } \\
\text { sharing }\end{array}$ & $\begin{array}{l}\text { The degree of resource sharing, such } \\
\text { as information, budget, and workforce, } \\
\text { with partners }\end{array}$ & $1-7$ & $\begin{array}{l}\text { Have partner organizations (including } \\
\text { your organization) combined and used } \\
\text { each other's resources, such as budget } \\
\text { or human resources, so all partners } \\
\text { benefit from collaborating? } \\
\text { Does your organization share } \\
\text { information with partner organizations } \\
\text { that will strengthen operations and } \\
\text { programs? }\end{array}$ \\
\hline $\begin{array}{c}\text { Trust- } \\
\text { building }\end{array}$ & $\begin{array}{l}\text { The level of trust-building with each } \\
\text { partner }\end{array}$ & $1-7$ & $\begin{array}{l}\text { Do you think that collaboration with } \\
\text { partners is a more effective method for } \\
\text { achieving project performance than } \\
\text { work alone? } \\
\text { Do you think your partner organizations } \\
\text { in the collaboration are trustworthy? } \\
\text { Do you think it worthwhile that your } \\
\text { organization stay and work with } \\
\text { partner organizations rather than leave } \\
\text { the collaboration? }\end{array}$ \\
\hline $\begin{array}{l}\text { Resource } \\
\text { munificence }\end{array}$ & $\begin{array}{l}\text { The project budget per year of total } \\
\text { project duration }\end{array}$ & $\begin{array}{l}\text { Open- } \\
\text { ended }\end{array}$ & $\begin{array}{l}\text { How much was the annual budget for } \\
\text { the project? }\end{array}$ \\
\hline $\begin{array}{l}\text { Network } \\
\text { management } \\
\text { capacity }\end{array}$ & $\begin{array}{l}\text { The length of the period for project } \\
\text { managers who worked in the field }\end{array}$ & $1-7$ & $\begin{array}{l}\text { How long have you worked in the field } \\
\text { to manage the project? }\end{array}$ \\
\hline $\begin{array}{l}\text { Local } \\
\text { capacity }\end{array}$ & $\begin{array}{l}\text { The degree of abundance of } \\
\text { resourceful and committed local } \\
\text { partners }\end{array}$ & $1-7$ & $\begin{array}{l}\text { When carrying out the project, how } \\
\text { many resourceful and committed local } \\
\text { partners were on the project site? When } \\
\text { carrying out the project, how many } \\
\text { resourceful and committed local } \\
\text { partners were on the project site? }\end{array}$ \\
\hline
\end{tabular}

development strategies of the local area where the project was implemented and relevance to beneficiaries' development needs. The mean value for each sub-indicator was calculated. Effectiveness was measured by one indicator: the extent to which the project achieved its goals. Efficiency was measured by how efficiently project budgets and personnel were used to generate better performance. Finally, sustainability was measured by four sub-indicators: sustainability of interest in the project and support from local governments and policymakers, sustainability of budget and labor support from the local community, sustainability of plans to manage buildings or equipment provided to locals, and sustainability of well-trained local labor after the departure of the project implementers. The mean values for four sub-indicators were calculated. Higher scores on a 7-point Likert scale indicated better network effectiveness.

Network integration ("I") was measured by network centrality. It was measured by a question regarding communication frequency between collaborators. Based on the respondents' list of partners, a list of up to 10 collaborative partners (institutions or groups) according to their project was generated in order of importance for project implementation. Response options of communication frequency were "Not at all," "Once a year," "Once every 6 months," "Once a quarter," "Once a month," "Once every two weeks," "Once a week," and "Every day." Higher scores on an 8-point Likert scale indicated frequent communication. These data were recoded into values of " 0 " (1-4) or "1" (5-8). Centrality scores were calculated on the basis of Freeman's degree of centrality (Freeman, 1978), using UCINET version 6.0 (Borgatti et al., 2002).

Next, we assessed the quality of collaboration ("C"), referring to norms among partners in the network. Norms were measured through two sub-indicators from surveys by Thomson et al. (2009) and Graddy and Chen (2006): the degree of resource sharing and the level of trust-building. Resource sharing was measured through two questions: "Have partner organizations (including your organization) combined and used each other's resources, such as budget 
or human resources, so all partners benefit from collaborating?" and "Does your organization share information with partner organizations that will strengthen operations and programs?" Trust-building was measured through three questions: "Do you think that collaboration with partners is an effective method for achieving project performance than work alone?", "Do you think your partner organizations in the collaboration are trustworthy?", and "Do you think worthwhile that your organization to stay and work with partner organizations rather than leave the collaboration?" Data from each sub-indicator were calculated into a mean value and summed to obtain one norm's value. All questions were measured on a 7-point Likert scale ranging from not at all to to a great extent. Higher scores in the dimensions of norms indicated better collaboration.

Resource munificence ("R") was measured by the project budget per year of total project duration. Higher scores indicated a greater project budget per year. The length of the period for project managers who worked in the field was used to measure network management capacity ("M"). Finally, to measure the presence of capable local partners ("L"), a 7-point Likert scale that asked about the availability of resourceful and committed local partners in the field was used, with higher scores indicating greater abundance of such partners.

\section{Data Analysis}

This study applied the explanatory sequential mixedmethods approach (Creswell, 2014) conducting the fs/QCA analysis first and then the case study.
For the fs/QCA data analysis, we first converted raw data for the casual conditions and outcome into fuzzy membership scores from 0 to 1 using fs/QCA version 3.0. These scores were calibrated on the basis of three cutoff points: 1 ("fully in"), 0.5 ("crossover point"), and 0 ("fully out"). In general, three cutoff points are selected on the basis of theoretical evidence, but they can also be decided on the basis of the distribution of data, which can be confirmed by using standard deviations if there is no theoretical basis (Ragin, 2000). Calibration of each causal condition and outcome variable was decided based on different criteria, depending on the distribution of their values. Network centrality, quality of collaboration (resource sharing and trust), resource munificence, network management capacity, and network effectiveness were calibrated using means and standard deviations. Local capacity was calibrated using minimum, median, and maximum values. The fuzzy membership scores of causal conditions and outcome are shown in Table 5.

For the analysis of in-depth interviews for the case study, a typical qualitative data analysis method was applied as suggested by Corbin and Strauss (2014). First, each of the authors read the manuscript repeatedly and tried to understand the distinctive background and context that induced the successful network effectiveness, focusing on the causal conditions uncovered from the fs/QCA. The authors open-coded the raw data of transcripts to identify key concepts, words, and statements such as the duration of field experiences, trustworthy relationships with partners, and collaboration motivations. Then, they categorized the codes into themes according to similar meanings, aligning them with the results of the fs/QCA. In the process of analysis, the authors shared and discussed their individual

Table 2 Descriptive statistics of causal conditions and outcome $(N=37)$

\begin{tabular}{|c|c|c|c|c|c|}
\hline Variables & $N$ & Mean & SD & Min & Max \\
\hline \multicolumn{6}{|l|}{ Outcome } \\
\hline Network effectiveness & 37 & 5.66 & 0.85 & 2.88 & 7 \\
\hline Relevance & 37 & 6.23 & 1.03 & 2 & 7 \\
\hline Effectiveness & 37 & 5.62 & 1.11 & 2 & 7 \\
\hline Efficiency & 37 & 5.76 & 1.07 & 3 & 7 \\
\hline Sustainability & 37 & 5.03 & 1.05 & 2.5 & 7 \\
\hline \multicolumn{6}{|l|}{ Causal conditions } \\
\hline Network integration (network centrality, 0-100) & 37 & 34.79 & 18.04 & 0 & 80 \\
\hline Quality of Collaboration & 37 & 11.01 & 1.61 & 7.44 & 14 \\
\hline Resource sharing (1-7) & 37 & 5.00 & 1.16 & 2.80 & 7 \\
\hline Trust-building (1-7) & 37 & 6.01 & 0.71 & 4.09 & 7 \\
\hline Resource munificence (project budget per year, million KRW) & 37 & 595 & 533 & 0 & 2250 \\
\hline Network management capacity (field period, month) & 37 & 26.33 & 15.12 & 12 & 84 \\
\hline Local capacity (resourceful and committed local partners, 1-7) & 37 & 4.22 & 1.36 & 1 & 7 \\
\hline
\end{tabular}


Table 3 Truth table $(N=37)$

\begin{tabular}{|c|c|c|c|c|c|c|c|}
\hline \multicolumn{5}{|c|}{ Causal conditions } & \multirow{2}{*}{$\begin{array}{l}\text { Outcome } \\
\text { Network } \\
\text { effectiveness (O) }\end{array}$} & \multirow{2}{*}{$\begin{array}{l}\text { Consistency } \\
\text { Raw } \\
\text { consistency }\end{array}$} & \multirow{2}{*}{$\begin{array}{l}\text { Number of } \\
\text { cases }\end{array}$} \\
\hline $\begin{array}{l}\text { Network } \\
\text { integration (I) }\end{array}$ & $\begin{array}{l}\text { Quality of } \\
\text { collaboration (C) }\end{array}$ & $\begin{array}{l}\text { Resource } \\
\text { munificence }(\mathrm{R})\end{array}$ & $\begin{array}{l}\text { Network management } \\
\text { capacity }(\mathrm{M})\end{array}$ & $\begin{array}{l}\text { Local } \\
\text { capacity (L) }\end{array}$ & & & \\
\hline 1 & 1 & 0 & 0 & 0 & 1 & 0.926316 & 1 \\
\hline 1 & 1 & 0 & 0 & 1 & 1 & 0.911067 & 2 \\
\hline 0 & 1 & 1 & 0 & 1 & 1 & 0.877551 & 2 \\
\hline 0 & 1 & 0 & 0 & 1 & 1 & 0.869359 & 1 \\
\hline 1 & 1 & 0 & 1 & 1 & 1 & 0.869301 & 1 \\
\hline 0 & 1 & 0 & 0 & 0 & 1 & 0.851163 & 2 \\
\hline 0 & 0 & 1 & 0 & 1 & 1 & 0.845735 & 4 \\
\hline 0 & 1 & 0 & 1 & 0 & 1 & 0.831169 & 1 \\
\hline 0 & 0 & 1 & 1 & 0 & 1 & 0.828125 & 1 \\
\hline 1 & 1 & 1 & 1 & 0 & 1 & 0.815562 & 1 \\
\hline 0 & 0 & 0 & 0 & 1 & 1 & 0.809210 & 1 \\
\hline
\end{tabular}

qualitative analysis, whether each analysis and interpretation was valid. Finally, the surveyed quantitative data, such as network degree centrality and project budget per year, were also reviewed to accurately understand the qualitative data.

The quantitative and qualitative data were combined to make the analytic results from the two methods more reasonable and "mutually illuminating" (Bryman, 2007: 21). Through the fs/QCA analysis, if the network effectiveness was high in a project in which the project manager with little field experience paid attention to the quality of collaboration with partners, we explored the distinctive background or motivation why the project manager made an effort to build a trustworthy relationship with partners, although the importance of the collaborative relationship is to be found in the tactical knowledge that is hard to accumulate in a short period.

\section{Results}

\section{Sample Characteristics}

We analyzed the characteristics of the respondents and international development interventions in which respondents were in charge of management and implementation $(N=37)$. Of all responders, $54.1 \%$ were males and $45.9 \%$ were females. The Korea-originated organizations constituted $75.7 \%$ and the international NGO-originated organizations (i.e., Save the Children, World Vision, etc.) constituted $24.3 \%$. The average age of the respondents was 34.03 years. On average, the total number of dispatched countries per respondent was 1.62 , and the total period of dispatch to local areas was 37.27 months. The average total duration of employment in the field of international development was 71.46 months (Table 6).

In addition, the majority of the projects were conducted in Africa (70.3\%) and the remaining in Asia (29.7\%). In terms of sectors, the proportion of regional development (35.1\%) was the highest, followed by health $(21.6 \%)$, drinking water/sanitation (13.5\%), education (13.5\%), and others $(16.2 \%)$. On average, the total project duration was 39.76 months, and the total project budget was 1.956 billion KRW (South Korean won, approximately USD 1.644 million). Lastly, the average total number of partners was 7.59; of all partners, Korean-affiliated- and local-affiliatedpartners constituted $18.4 \%$ and $81.62 \%$, respectively (Table 7).

The descriptive statistics of causal conditions and outcome are described in Table 2.

\section{Analytic Results}

According to the truth table for causal conditions, which displays all logically possible causal conditions and outcome as well as the presence of a causal relationship between each condition (Ragin, 2009), 18 of the 32 logically possible combinations (i.e., $2^{5}$ ) led to successful outcomes. Among the combinations generated in the truth table (Table 3), eleven configurations were found to be combinations of causal conditions for the outcome. Among the ten configurations, we accepted two casual condition combinations as sufficient configurations for network effectiveness, because they achieved a valid level of consistency (above 0.8) and coverage (above 0.3) (Table 4).

The following equation reveals the two causal combination configurations that lead to network effectiveness: 
$m * i * L+m * r * C \rightarrow O$ (coverage: 0.733045, consistency: 0.846196)

According to the equation, Path 1 shows that even if the project manager was inexperienced $(m)$ and the network was not centrally integrated $(i)$, a large number of resourceful and committed local partners $(L)$ can lead to network effectiveness. In addition, Path 2 shows that even if the project manager was not sufficiently experienced $(m)$ and a volume of the project budget was small $(r)$, good quality of collaborative processes characterizing high level of resource sharing and trust among partners $(C)$ can bring out network effectiveness.

\section{Case Study}

We selected case 26 in Path $1\left(m^{*} i^{*} L\right)$ and case 9 in Path 2 $\left(m^{*} r^{*} C\right)$ to explore the mechanisms of how network effectiveness was derived from these configurations. Indepth interviews were conducted with the project managers of case 26 and case 9. In addition, survey data were analyzed to understand the context of the causal combinations.

First, case 26 in Path 1 was the "Drinking Water/Hygiene and Health Improvement Project," conducted in Cambodia during 3 years from 2015 to 2017. The volume of the project budget per year was 176 million KRW (approximately USD 148,000). Through this project, public toilets and shower booths were installed in each village, and hygiene-related practices and knowledge were delivered to the participants by various education and training programs. For the manager who was in charge of the project, it was the first opportunity to manage a development project in the field, and she was therefore relatively inexperienced in the field $(m)$. Of the five partners of the network generated to calculate network size, $80 \%$ was affiliated in the local and the remainder (20\%) was affiliated in Korea. The network was not centrally integrated (i) because the score of the network centrality was $32 \%$, which is below the cutoff point of $0.5(34.79 \%)$.

However, case 26 had resourceful and committed local partners including village chiefs, local directors, and local staff. For example, while other NGOs had difficulties in accessing the local administration system and getting the project approval from the local government, the local director of this project, who had extensive experiences as an official in central and local governments, made it easy to access the local officials using his local networks.

Usually, other NGOs experience numerous difficulties in contacting the local government to gain approval to implement the project. It's extremely time-consuming to obtain the approval. However, in my case, the local project director worked closely with the provincial governors [in the local project area], so it was easy to contact the [local] governors. There were many people who had worked with the director, so it was a bit easier to start and conduct the project. (Case 26 manager)

Village chiefs also provided tremendous support and commitments to effectively educate and involve themselves with the community members in the project. In the initial stage of the project, community chiefs and villagers recommended appropriate places to the project manager where public toilets and shower booths could be installed-near the residence where most people with disabilities or the elders lived. A fair selection of locations was very important to prevent potential conflicts among community members. Community chiefs also helped the project manager by collecting community members' opinions and suggestions to improve the implementation process of the project. Additionally, local staff were committed to the successful outcome of the project. In particular, they willingly shared knowledge and information about the local people and culture with the project manager so that they could gain a better understanding of the community.

Before we built it [public toilet], we looked around the community with the community chief and several residents. During that time, they recommended the proper place to establish the toilets because they mostly knew the places well. Then we visited the location again, gathered all the residents, and agreed

Table 4 Configurations leading to network effectiveness $(N=37)$

\begin{tabular}{llllll}
\hline & Configurations & Raw coverage & Unique coverage & Consistency & Cases (case number) \\
\hline Path 1 & $m * i^{*} L$ & 0.407888 & 0.145262 & 0.871531 & $2,5,14,18,26,28,32,34$ \\
Path 2 & $m * r * \mathrm{C}$ & 0.354016 & 0.032708 & 0.848904 & $1,2,9,10,11,19,30,37$
\end{tabular}

Solution coverage: 0.733045

Solution consistency: 0.846196

Frequency cutoff $=1$, consistency cutoff: 0.809210

(Path 1) $m=$ lack of management capacity, $i=$ low level of network integration, $L=$ high level of local capacity; (Path 2) $m=$ lack of management capacity, $r=$ lack of resource, $C=$ high quality of collaboration 
that the recommended places were appropriate for public toilets. They stated, "Here live the disabled who find it difficult to walk with one leg. So the toilets around his house need to be established." We always discussed it in this way. (Case 26 manager)

Case 9 in Path 2 was the "Capacity-building Program for Teachers in Primary School" implemented in Uganda for 3 years from 2016 to 2018 . The volume of the project budget per a year was relatively small (433 million KRW, approximately USD 365,000) compared with other cases $(r)$. The project was the first one that the project manager had managed $(m)$. The network size of case 9 was seven, and $72.43 \%$ were affiliated in the local and the remainder (28.57\%) was affiliated in Korea. Most local partners were teachers of elementary schools. At the beginning of the project, the project manager tried hard to make trustworthy relationships among partners $(C)$. For example, she made frequent visits to the project sites to build trust with the local partners. Despite that it was beyond the assigned duty of the project manager, she regularly visited the sites once a week in order to remember faces and names of teachers, to share information and knowledge on education issues, and to build a strong collaborative relationship with them.

We didn't actually need to [monitor the project] every week, but I thought we needed to go. That way, we could hear the voices in the field and remember the [local teachers'] faces and names to collaborate with them more often. I thought these things were important to smoothly conduct the project, despite it being a little hard. I think meeting them once a week was the greatest effort a facilitator could put forth to build trust with [local] partners. (Case 9 manager)

In addition, at the official meetings, the project manager tried not to criticize teachers' performance, but instead to listen carefully to their needs to improve capacity as teachers. She tried to show them that the project manager is not a critic, but a collaborator for achieving the project goals together. As these efforts had been continued, local teachers not only built strong trust in the project manager but also strengthened their capacity as teachers.

We didn't teach the teachers directly. Instead of giving them our feedback, we let them exchange their opinions and feedback with each other. While we visited the school to monitor the class, we continued to insist that the fundamental purpose of our monitoring '[was] not to criticize you [teachers], but we are coming to strengthen your capabilities as the teachers to teach your students well.' [...] We tried not to get involved in the teachers' activities. For example, we just let the teachers lead the school meetings themselves. We didn't give feedback such as 'I think you are wrong or well.' Frankly, the teachers didn't seem to show much improvement at first, and they seemed to be the same every day. However, soon after, I became convinced that since we were less involved in this way, the improvement of the teachers' capabilities became quickly apparent. (Case 9 manager)

By trusting local partners, the case 9 manager respected their autonomy to become subjects of the project and do their own activities. Moreover, the manager also entrusted some of the project content that only project managers from donor countries had been involved in, so that local teachers could plan programs and establish budgets themselves. This was a difficult decision to make without deep trust and respect for the teachers. Through this process, the teachers learned how to plan programs to solve school problems, which ultimately functioned as a useful strategy for program sustainability.

There was a program whereby teachers had to do what we [the project team] were doing. While the results were unsatisfactory at some schools, I think that this process was necessary for them and us after the end of the project. [...] If we had continued in the same way as we ran all of our activities before, the teachers couldn't learn how to carry out the program. However, the process of planning a program and a budget by themselves and devising how to solve school problems by creating a program was useful as our exit strategy. (Case 9 manager)

From case 9, we can understand how a collaborative network, which did not have a large budget and was managed by an inexperienced project manager, can meet the goals of the network through good quality of collaboration by sharing resources and building trustworthy relationships with partners. In contrast to previous literature that argued the importance of experienced managers in the field for effective network management, the case study showed that the mere length of the dispatched period or extensive field experiences do not guarantee effective network management.

\section{Discussion}

Combining the fs/QCA method and the case study, this study examined causal combinations leading to the network effectiveness of international development projects and explored the distinctive context inducing the results of fs/QCA. As causal conditions for network effectiveness in the context of international development, network integration, quality of collaboration, resource munificence, 
management capacity, and local capacity were selected, and how they were configured for network effectiveness was explored. Our analysis shows that network effectiveness can be explained through two different sets of configurations. First, despite the lack of management capacity and the low level of network integration, network effectiveness was achieved if local capacity was at a high level $\left(m^{*} i^{*} L\right)$. Furthermore, even in the condition of low management capacity and resources, network effectiveness was achieved if the quality of collaboration among partners was strong based on trustworthy relationship and sharing resources $\left(m^{*} r^{*} C\right)$. These findings allowed us to theoretically and practically understand how we improve network effectiveness through configurations of causal conditions in the field of international development.

First, local capacity, which was measured by the presence of resourceful and committed local partners, was found to be a necessary condition for network effectiveness-despite limitations in a managerial capacity and in an unintegrated network. These findings seem to contrast with some previous studies that have shown that networks not centrally integrated (Alexander, 2012; Milward et al., 2009; Provan \& Milward, 1995) or managed by unskillful managers (Khang \& Moe, 2008; Muriithi \& Crawford, 2003; Struyk, 2007; White \& Fortune, 2002) generally lead to project failure or network ineffectiveness. The finding of this study suggests that conditions may compensate with each other to lead network effectiveness by configuration; as shown in previous studies, the presence of resourceful and committed partners are the most critical in achieving project performance (Khang \& Moe, 2008; Pfeiffer, 2003). Case 26 of this study corroborates this finding as it shows how even unskillful managers in unintegrated network can achieve network effectiveness. In this case, there were committed local partners who skillfully communicated with key local politicians and beneficiaries. Consistent with previous literature (Bano, 2018), for NGOs it is important to have extensive knowledge of and connection with governmental bureaucrats to effectively implement development projects by making partnerships.

In our study, of the average total number of partners, locally affiliated partners were about $80 \%$, thus local partners' commitment may exert a significant influence on network effectiveness. Therefore, to achieve network effectiveness in the international development context, it would be important to have plans to strategically find and collaborate with resourceful and committed local partners. As one of the practical solutions, NGOs from the donors' perspective need to share information of resourceful and committed local partners or collaborate with local NGOs to find and select the appropriate partners. Additionally, development NGOs need to provide local partners with opportunities for education and training to improve capacity to plan, implement, and evaluate projects.

In establishing trustworthy relationships with local partners through genuine collaboration, the power and experiences of the donor should be designed to transfer to the local partners. This also becomes important in the current scenario of the COVID-19 pandemic. While dispatched project managers from donor countries should leave the site, local partners should remain on-site and complete the project. Accordingly, NGOs need to plan their exit as an opportunity to actively transfer power related to decision making, administration, and evaluation to local partners to strengthen their ability to execute projects on their own.

Second, this study showed that the quality of collaboration was another critical condition to achieve network effectiveness, which compensates inexperienced managers and small project budgets. Consistent with previous literature which explored the process of collaboration and its effectiveness (Chen, 2008; Curnin, \& O'Hara, 2019; Huxham, 2003; Huxham \& Vangen, 2013; Mondal, 2000; Moynihan, 2005; Singh \& Prakash, 2010; Waugh, 2003; Willem \& Lucidarme, 2014), this study provided evidence to support that mutual resource sharing and trust building are the major conditions for network effectiveness. According to case 9, even an inexperienced manager of a small-scale project can achieve network effectiveness by making trustworthy relationships with partners.

However, it must be noted that the process of trustbuilding and resource sharing is a time-consuming task (Huxham, 2003; Huxham \& Vangen, 1996). Often, project managers experience conflicts among the partners and struggle to achieve the targeted goals within the planned project period. Between achieving goals and building the process of collaboration, they have to choose goal achievement, thus sacrificing collaboration building. If building and maintaining strong collaboration is a timeconsuming task but is a critical condition for network effectiveness, how can we resolve this contradiction? As a partial solution to resolve the problem, the headquarters, the funders, and project managers should share the understanding of difficulties in managing the process of collaboration. It is important for the headquarters of NGOs and the funders to have shared understanding about the importance of quality of collaboration instead of pushing for immediate outcomes and pressing project managers toward maintaining their accountability toward donors.

Finally, one of the practical suggestions generated from our study is for the headquarters of respective NGOs to strategically consider and configure their available resources, such as project budgets, a capable workforce, or local capacity, before undertaking international development interventions. Indeed, local contexts for international 
development projects are diverse, and the type and amount of resources available to NGOs may also vary depending on organizational or environmental circumstances. For example, an NGO is expected to achieve network effectiveness despite having an inexperienced manager and the lack of a project budget. In this condition, the NGO should support the project manager to effectively manage the process of collaboration focusing on resource sharing and trust-building in order to compensate for deficiency of other conditions.

Although this study investigated the causal combinations for network effectiveness of international development projects, several limitations should be mentioned. First, it measured network effectiveness and attributes of a collaborative network based on subjective self-ratings by the project manager of each project, which may be vulnerable to survey biases. Additionally, unlike the usual practice of surveying every participant in the network, the study surveyed network degree-centrality according to only one participant (project manager) because of the temporal and spatial accessibility limitations in the field of international development. Although McGuire and Silvia (2009) noted that network effectiveness can be accurately evaluated by the project manager-who has the most information about the project-each actor who participates in a collaborative network will have different perspectives and can provide a different assessment of the network's aspects and effectiveness (Head, 2008; Mandell \& Keast, 2007). For example, even though the project manager evaluated that information sharing and trust-building with local partners or network effectiveness were good enough, the local partners could make adverse assessments. To overcome this limitation, we asked project managers to evaluate the network features and effectiveness by considering overall partners' perspectives. However, we fell short of fully reflecting the diverse nature of partners' opinions, including local partners. Although this study relied on the evaluation of the project manager, reflecting the stakeholders' perspective is necessary to evaluate the project effectiveness; the same is true of the participatory or collaborative evaluation and monitoring approach, emphasizing stakeholders' active involvement in the entire process of program evaluation (O'Sullivan, 2012; RodriguezCampos, 2012). In future studies, both the project managers and other partners should participate in the survey and interviews to keep a balanced evaluation of the network effectiveness and its causal conditions.

Second, this study explored various kinds of intervention cases in diverse regions and sectors. Although this broad approach was limited to capturing the distinctive features of regions or sectors of the selected cases, this study tried to uncover the common critical causal conditions that improve network effectiveness in diverse features of cases under the small sample size. Future studies need to regard the regional or sectoral features of international development interventions to induce more sector- or region-tailored implications.

Finally, the total sample size of the study was limited to 37 cases, and future studies must replicate this study with a larger number of cases to generalize this study's results.

\section{Conclusion}

This study empirically explores the configurations of causal conditions for network effectiveness through a mixedmethods approach combining the fs/QCA and case study. It contributes to the existing research by adding empirical evidence on how the collaborative networks influence network effectiveness (Gray, 2003; Heranz, 2010; Lucidarme, et al., 2016; McGuire \& Silvia, 2009). Furthermore, unlike previous studies, which only described a simple and linear relationship between causal conditions and network effectiveness, this study demonstrates that multiple pathways exist for achieving network effectiveness, in the context of international development. Our consideration of the set-relationship between causal conditions can provide more realistic explanations of how each causal condition compensates in the causal combinations.

Based on the results, this study suggests practical management methods for collaborative networks. While most literature on collaboration in the field of international development has focused on PPP or aid coordination from the donor side, this study focuses on collaboration at the project level. This exploration was possible because the study emphasized that international development projects are generally implemented through collaboration among diverse entities. We applied theories of collaborative networks in the international development field and generated specific suggestions for project managers and head offices of NGOs. The findings of this study will aid policymakers and practitioners of NGOs to strategically configure their available resources and management skills to achieve network effectiveness.

Authors' Contribution Conceptualization, design, material preparation, data collection and analysis were performed by SH. The first draft of the manuscript was written by $\mathrm{SH}$ and the manuscript was critically reviewed and edited by MK. 


\section{Declarations}

Conflict of interest The authors declare that they have no conflict of interest.

Ethical Approval We obtained an ethical approval from the institutional review board of XX university on October 14, 2016 (No. 123-10). The survey was conducted after receiving consent for participation.

\section{Appendix}

See Tables 5, 6 and 7.

Table 5 Fuzzy membership scores for causal conditions and outcomes for project cases $(N=37)$

\begin{tabular}{|c|c|c|c|c|c|c|}
\hline \multirow{2}{*}{$\begin{array}{l}\text { Crossover } \\
\text { point }\end{array}$} & \multicolumn{5}{|c|}{ Causal conditions } & \multirow{2}{*}{$\begin{array}{l}\text { Outcomes } \\
\text { Network } \\
\text { effectiveness }\end{array}$} \\
\hline & $\begin{array}{l}\text { Network } \\
\text { integration }\end{array}$ & $\begin{array}{l}\text { Quality of } \\
\text { collaboration }\end{array}$ & $\begin{array}{l}\text { Resource } \\
\text { munificence }\end{array}$ & $\begin{array}{l}\text { Network Management } \\
\text { capacity }\end{array}$ & $\begin{array}{l}\text { Local } \\
\text { capacity }\end{array}$ & \\
\hline $\mathbf{0}$ & 16.75 & 9.39 & 0.62 & 12.00 & 1.00 & 4.81 \\
\hline 0.5 & 34.79 & 11.01 & 5.95 & 37.27 & 4.00 & 5.66 \\
\hline 1 & 52.83 & 12.62 & 11.28 & 62.13 & 7.00 & 6.51 \\
\hline Case1 & 0.74 & 0.92 & 0.07 & 0.46 & 0.27 & 0.99 \\
\hline Case 2 & 0.28 & 0.93 & 0.23 & 0.05 & 0.95 & 0.53 \\
\hline Case3 & 0.21 & 0.97 & 0.07 & 0.58 & 0.27 & 0.63 \\
\hline Case 4 & 0.61 & 0.16 & 0.28 & 0.05 & 0.88 & 0 \\
\hline Case 5 & 0.18 & 0.99 & 0.55 & 0.05 & 0.88 & 0.77 \\
\hline Case6 & 0.13 & 0.57 & 0.97 & 0.4 & 0.27 & 0.84 \\
\hline Case 7 & 0.04 & 0.09 & 0.83 & 0.46 & 0.5 & 0.36 \\
\hline Case8 & 0.95 & 0.35 & 0.07 & 1 & 0.88 & 0.91 \\
\hline Case9 & 1 & 0.97 & 0.29 & 0.05 & 0.88 & 0.58 \\
\hline Case 10 & 0.97 & 0.83 & 0.19 & 0.06 & 0.5 & 0.84 \\
\hline Case11 & 0.39 & 0.64 & 0.13 & 0.17 & 0.5 & 0.47 \\
\hline Case 12 & 0.08 & 0.23 & 0.91 & 0.05 & 0.27 & 0 \\
\hline Case 13 & 1 & 0.08 & & 0.17 & 0.27 & 0.01 \\
\hline Case14 & 0.06 & 0.04 & 0.96 & 0.17 & 0.73 & 0.91 \\
\hline Case 15 & 0.83 & 0.06 & 0.11 & 0.74 & 0.5 & 0.27 \\
\hline Case16 & 0.59 & 0.31 & 0.31 & 1 & 0.27 & 0.04 \\
\hline Case17 & 0.88 & 0.2 & 0.06 & 0.05 & 0.5 & 0.32 \\
\hline Case18 & 0.16 & 1 & 0.71 & 0.07 & 0.73 & 0.98 \\
\hline Case19 & 0.88 & 0.95 & 0.15 & 0.1 & 0.73 & 0.73 \\
\hline Case20 & 0.99 & 0.77 & 0.07 & 0.58 & 0.73 & 0.73 \\
\hline Case21 & 0.41 & 0.03 & 0.06 & 0.99 & 0.88 & 0 \\
\hline Case22 & 0.11 & 0.83 & 1 & 0.17 & 0.12 & 0.36 \\
\hline Case23 & 0.05 & 0.97 & 0.25 & 1 & 0.5 & 0.99 \\
\hline Case24 & 0.99 & 0.86 & 1 & 0.96 & 0.27 & 0.77 \\
\hline Case25 & 0.61 & 0.11 & 0.05 & 0.96 & 0.27 & 0.89 \\
\hline Case26 & 0.39 & 0.11 & 0.09 & 0.4 & 0.88 & 0.58 \\
\hline
\end{tabular}


Table 5 continued

\begin{tabular}{|c|c|c|c|c|c|c|}
\hline \multirow{2}{*}{$\begin{array}{l}\text { Crossover } \\
\text { point }\end{array}$} & \multicolumn{5}{|c|}{ Causal conditions } & \multirow{2}{*}{$\begin{array}{l}\text { Outcomes } \\
\text { Network } \\
\text { effectiveness }\end{array}$} \\
\hline & $\begin{array}{l}\text { Network } \\
\text { integration }\end{array}$ & $\begin{array}{l}\text { Quality of } \\
\text { collaboration }\end{array}$ & $\begin{array}{l}\text { Resource } \\
\text { munificence }\end{array}$ & $\begin{array}{l}\text { Network Management } \\
\text { capacity }\end{array}$ & $\begin{array}{l}\text { Local } \\
\text { capacity }\end{array}$ & \\
\hline Case27 & 0.8 & 0.33 & 0.97 & 0.61 & 0.5 & 0.68 \\
\hline Case28 & 0.06 & 0.04 & 0.96 & 0.17 & 0.73 & 0.91 \\
\hline Case29 & 0.08 & 0.99 & 0.06 & 0.84 & 0.5 & 0.32 \\
\hline Case 30 & 0 & 1 & 0.17 & 0.06 & 0.27 & 0.94 \\
\hline Case31 & 0.25 & 0.1 & 0.61 & 0.78 & 0.27 & 0.94 \\
\hline Case 32 & 0 & 0.05 & 0.98 & 0.46 & 0.88 & 0.47 \\
\hline Case33 & 0.8 & 0 & 0.31 & 0.78 & 0.27 & 0.53 \\
\hline Case34 & 0.47 & 0.01 & 0.96 & 0.3 & 0.73 & 0.68 \\
\hline Case 35 & 0.97 & 0.06 & 0.25 & 0.17 & 0.5 & 0.53 \\
\hline Case36 & 0.59 & 0.56 & 0.9 & 0.89 & 0.73 & 0.03 \\
\hline Case37 & 0.02 & 0.59 & 0.19 & 0.16 & 0.05 & 0.27 \\
\hline
\end{tabular}

Table 6 Characteristics of respondents (project managers) $(N=37)$

\begin{tabular}{|c|c|c|c|c|}
\hline \multicolumn{2}{|l|}{ Characteristics } & \multicolumn{3}{|c|}{ No. of responders } \\
\hline \multicolumn{5}{|l|}{ Gender } \\
\hline Male & & \multicolumn{3}{|c|}{$20(54.1 \%)$} \\
\hline Female & & \multicolumn{3}{|c|}{$17(45.9 \%)$} \\
\hline \multicolumn{5}{|l|}{ Features of organization } \\
\hline \multicolumn{2}{|l|}{ Korea-originated } & \multicolumn{3}{|c|}{$28(75.7 \%)$} \\
\hline \multicolumn{2}{|l|}{ International NGO-originated } & \multicolumn{3}{|c|}{$9(24.3 \%)$} \\
\hline Characteristics & Mean & $\mathrm{SD}$ & Min & Max \\
\hline Age (year) & 35.03 & 4.95 & 26 & 44 \\
\hline $\begin{array}{l}\text { Total number of dispatched } \\
\text { countries }\end{array}$ & 1.62 & 1.01 & 1 & 5 \\
\hline $\begin{array}{l}\text { Total period of dispatched in locals } \\
\text { (month) }\end{array}$ & 37.27 & 24.86 & 12 & 110 \\
\hline $\begin{array}{l}\text { Total duration of employment in the } \\
\text { field of dev. (month) }\end{array}$ & 71.46 & 40.997 & 12 & 114 \\
\hline
\end{tabular}

Table 7 Characteristics of international development interventions (projects) $(N=37)$

\begin{tabular}{|c|c|c|c|c|c|}
\hline Characteristics & \multicolumn{2}{|l|}{ Features } & \multicolumn{3}{|c|}{ No. of responders } \\
\hline \multirow[t]{2}{*}{ Project region } & \multicolumn{2}{|l|}{ Africa } & \multicolumn{3}{|c|}{$26(70.3 \%)$} \\
\hline & \multicolumn{2}{|l|}{ Asia } & \multicolumn{3}{|c|}{$11(29.7 \%)$} \\
\hline \multirow[t]{5}{*}{ Project areas } & \multicolumn{2}{|c|}{ Regional development } & \multicolumn{3}{|c|}{$13(35.1 \%)$} \\
\hline & \multicolumn{2}{|l|}{ Health } & \multicolumn{3}{|c|}{$8(21.6 \%)$} \\
\hline & \multicolumn{2}{|c|}{ Drink water/sanitation } & \multicolumn{3}{|c|}{$5(13.5 \%)$} \\
\hline & \multicolumn{2}{|l|}{ Education } & \multicolumn{3}{|c|}{$5(13.5 \%)$} \\
\hline & \multicolumn{2}{|l|}{ Others } & \multicolumn{3}{|c|}{$6(16.2 \%)$} \\
\hline \multicolumn{2}{|l|}{ Characteristics } & Mean & SD & Min & Max \\
\hline \multicolumn{2}{|c|}{ Total project duration (month) } & 39.76 & 16.33 & 24 & 120 \\
\hline \multicolumn{2}{|c|}{ Total project budget (billion KRW) } & 1.956 & 1.898 & 13 & 9.000 \\
\hline \multicolumn{2}{|c|}{ Total number of partners } & 7.59 & 2.35 & 2 & 10 \\
\hline \multicolumn{6}{|c|}{ Partners' affiliation } \\
\hline \multicolumn{2}{|l|}{ Korea $(\%)$} & 18.40 & 11.24 & 0 & 50 \\
\hline \multicolumn{2}{|l|}{ Local (\%) } & 81.62 & 11.21 & 50 & 100 \\
\hline
\end{tabular}




\section{References}

Abdenur, A. E., \& Marcondes-Neto, D. (2014). Rising powers and the security-development nexus: Brazil's engagement with GuineaBissau. Journal of Peacebuilding and Development, 9(2), 1-16.

Abdullah, A., \& Khadaroo, I. (2020). The trust-control nexus in public private partnership (PPP) contracts. Journal of Accounting and Public Policy, 39(6), 106768.

AbouAssi, K., Makhlouf, N., \& Whalen, P. (2016). NGOs' resource capacity antecedents for partnerships. Nonprofit Management \& Leadership, 26(4), 435-451.

Agranoff, R., \& McGuire, M. (2004). Collaborative public management: New strategies for local governments. Georgetown University Press.

Alexander, R. (2012). Network structures and the performance of brownfield redevelopment PPPs. Public Performance \& Management Review, 35(4), 753-768.

Ameyaw, E. E., \& Chan, A. P. (2013). Identifying public-private partnership (PPP) risks in managing water supply projects in Ghana. Journal of Facilities Management., 1(2), 152-182.

Bano, M. (2011). Negotiating collaboration in Pakistan: Expertise, networks and community embeddedness. Public Administration and Development, 31(4), 262-272.

Bano, M. (2018). Partnerships and the good-governance agenda: Improving service delivery through state-NGO collaborations. VOLUNTAS: International Journal of Voluntary and Nonprofit Organizations, 30(6), 1270-1283.

Barnes, A., \& Brown, G. W. (2011). The Idea of Partnership within the Millennium Development Goals: Context, instrumentality and the normative demands of partnership. Third World Quarterly, 32(1), 165-180.

Bigsten, A., \& Tengstam, S. (2015). International coordination and the effectiveness of aid. World Development, 69, 75-85.

Borgatti, S. P., Everett, M. G., \& Freeman, L. C. (2002). Ucinet for Windows: Software for social network analysis. Analytic Technologies..

Brinkerhoff, J. M. (2003). Donor-funded government-NGO partnership for public service improvement: Cases from India and Pakistan. VOLUNTAS: International Journal of Voluntary and Nonprofit Organizations, 14(1), 105-122.

Bryman, A. (2007). Barriers to integrating quantitative and qualitative research. Journal of Mixed Methods Research, 1(1), 8-22.

Bryson, J. M., Crosby, B. C., \& Stone, M. M. (2006). The design and implementation of cross-sector collaborations: Propositions from the literature. Public Administration Review, 66(s1), 44-55.

Chataway, J., \& Smith, J. (2006). The International AIDS Vaccine Initiative (IAVI): Is it getting new science and technology to the world's neglected majority? World Development, 34(1), 16-30.

Chen, B. (2008). Assessing interorganizational networks for public service delivery: A process-perceived effectiveness framework. Public Performance \& Management Review, 31(3), 348-363.

Chen, B., \& Graddy, E. A. (2010). The effectiveness of nonprofit lead-organization networks for social service delivery. Nonprofit Management \& Leadership, 20(4), 405-422. https://doi.org/10. $1002 / \mathrm{nml} .20002$

Cleland, D. I., \& King, W. R. (1975). Systems analysis and project management. McGraw-Hill Book Company.

Corbin, J., \& Strauss, A. (2014). Basics of qualitative research: Techniques and procedures for developing grounded theory. Sage.

Creswell, J. W. (2014). Research design: Qualitative, quantitative, and mixed methods approaches. Sage.

Cristofoli, D., Trivellato, B., \& Verzillo, S. (2019). Network management as a contingent activity. A configurational analysis of managerial behaviors in different network settings. Public Management Review, 21(12), 1775-1800.

Curnin, S., \& O'Hara, D. (2019). Nonprofit and public sector interorganizational collaboration in disaster recovery: Lessons from the field. Nonprofit Management \& Leadership, 30(2), 277-297.

Czaja, R. (1998). Questionnaire pretesting comes of age. Marketing Bulletin-Department of Marketing Massey University, 9, 52-66.

Diallo, A., \& Thuillier, D. (2005). The success of international development projects, trust and communication: An African perspective. International Journal of Project Management, 23(3), 237-252.

Freeman, L. C. (1978). Centrality in social networks conceptual clarification. Social Networks, 1(3), 215-239.

Gazley, B. (2008). Intersectoral Collaboration and the Motivation to Collaborate: Toward an Integrated Theory. In Bingham, L., \& O'Leary, R. (Eds.), Big Ideas in Collaborative Public Management. Neywork: Routledge.

Gefen, D., Gefen, G., \& Carmel, E. (2016). How project description length and expected duration affect bidding and project success in crowdsourcing software development. Journal of Systems and Software, 116, 75-84.

Graddy, E. A., \& Chen, B. (2006). Influences on the size and scope of networks for social service delivery. Journal of Public Administration Research and Theory, 16(4), 533-552.

Gray, A. (2003). Collaboration in public services: The challenge for evaluation. Transaction.

Grindle, M. S. (2004). Good enough governance: Poverty reduction and reform in developing countries. Governance, 17(4), $525-548$

Grofman, B., \& Schneider, C. Q. (2009). An introduction to crisp set QCA, with a comparison to binary logistic regression. Political Research Quarterly, 62(4), 662-672.

Gulzar, L., \& Henry, B. (2005). Interorganizational collaboration for health care between nongovernmental organizations (NGOs) in Pakistan. Social Science \& Medicine, 61(9), 1930-1943.

Han, S. (2018). Attributes, barriers, and performance of collaborative networks: An empirical analysis on international development projects implemented by NGOs in South Korea. (Doctoral dissertation, Ewha Womans University, Seoul, South Korea).

Haque, M. S. (2004). Governance based on partnership with NGOs: Implications for development and empowerment in rural Bangladesh. International Review of Administrative Sciences, $70(2), 271-290$

Head, B. W. (2008). Assessing network-based collaborations: Effectiveness for whom? Public Management Review, 10(6), 733-749.

Heranz, J. (2010). Network performance and coordination: A theoretical review and framework. Public Performance \& Management Review, 33(3), 311-341.

Holmberg, S., \& Rothstein, B. (2011). Quality of government and access to safe water. QoG working paper series, 2011 (4), 4. Retrieved February 24, 2020 from https://www.sahlgrenska.gu. se/digitalAssets/1357/1357837_2011_4_holmberg_rothstein.pdf.

Hughes, K. A. (2004). Comparing pretesting methods: Cognitive interviews, respondent debriefing, and behavior coding. Survey Methodology, 2, 1-20.

Huxham, C. (2003). Theorizing collaboration practice. Public Management Review, 5(3), 401-423.

Huxham, C., \& Vangen, S. (1996). Working together: Key themes in the management of relationships between public and non-profit organizations. International Journal of Public Sector Management, 9(7), 5-17.

Huxham, C., \& Vangen, S. (2013). Managing to collaborate: The theory and practice of collaborative advantage. Routledge. 
Ika, L. A., Diallo, A., \& Thuillier, D. (2012). Critical success factors for World Bank projects: An empirical investigation. International Journal of Project Management, 30(1), 105-116.

Kamya, C., Shearer, J., Asiimwe, G., Carnahan, E., Salisbury, N., Waiswa, P., Brinkerhoff, J., \& Hozumi, D. (2017). Evaluating global health partnerships: A case study of a Gavi HPV vaccine application process in Uganda. International Journal of Health Policy and Management, 6(6), 327.

Khang, D. B., \& Moe, T. L. (2008). Success criteria and factors for international development projects: A life-cycle-based framework. Project Management Journal, 39(1), 72-84.

Lee, B., \& Lee, S. (2017). Winning conditions of precarious workers' struggles: A reflection based on case studies from South Korea. Relations Industrielles/industrial Relations, 72(3), 524-550.

Lee, S. (2014). Theory and Practice of fuzzy-set Qualitative Comparative Analysis ( $\left.f_{s} / Q C A\right)$. Korea University Press. in Korean.

Lucidarme, S., Cardon, G., \& Willem, A. (2016). A comparative study of health promotion networks: Configurations of determinants for network effectiveness. Public Management Review, 18(8), 1163-1217.

Mandell, M., \& Keast, R. (2007). Evaluating network arrangements: Toward revised performance measures. Public Performance \& Management Review, 30(4), 574-597.

Marcondes-Neto, D. (2014). Rising powers and the security-development nexus: Brazil's engagement with Guinea-Bissau. Journal of Peacebuilding and Development, 9(2), 1-16.

Martin, N. L., Pearson, J. M., \& Furumo, K. (2007). Is project management: Size, practices and the project management office. Journal of Computer Information Systems, 47(4), 52-60.

Mawdsley, E. (2017). Development geography 1: Cooperation, competition and convergence between 'North'and 'South.' Progress in Human Geography, 41(1), 108-117.

McGuire, J. W. (2010). Wealth, health, and democracy in East Asia and Latin America. Cambridge University Press.

McGuire, M., \& Silvia, C. (2009). Does leadership in networks matter? Examining the effect of leadership behaviors on managers' perceptions of network effectiveness. Public Performance \& Management Review, 33(1), 34-62.

Milward, H. B., \& Provan, K. G. (2006). A manager's guide to choosing and using collaborative networks (Vol. 8). Washington, DC: IBM Center for the Business of Government.

Milward, H. B., Provan, K. G., Fish, A., Isett, K. R., \& Huang, K. (2009). Governance and collaboration: An evolutionary study of two mental health networks. Journal of Public Administration Research and Theory, 20(Suppl_1), i125-i141.

Miraftab, F. (2004). Public-private partnerships: The trojan horse of neoliberal development? Journal of Planning Education and Research, 24(1), 89-101.

Mischen, P. A. (2015). Collaborative network capacity. Public Management Review, 17(3), 380-403. https://doi.org/10.1080/ 14719037.2013 .822527$.

Mondal, A. H. (2000). Social capital formation: The role of NGO rural development programs in Bangladesh. Policy Sciences, 33(3-4), 459-475.

Morrissey, J. P., Calloway, M., Bartko, W. T., Ridgely, M. S., Goldman, H. H., \& Paulson, R. I. (1994). Local mental health authorities and service system change: Evidence from the Robert Wood Johnson Foundation Program on Chronic Mental Illness. The Milbank Quarterly, 72, 49-80.

Moynihan, D. P. (2005). Leveraging collaborative networks in infrequent emergency situations. IBM Center for the Business of Government.

Muriithi, N., \& Crawford, L. (2003). Approaches to project management in Africa: Implications for international development projects. International Journal of Project Management, 21(5), 309-319.

O'Toole, L. J., Jr. (1997). Treating networks seriously: Practical and research-based agendas in public administration. Public Administration Review, 57(1), 45-52.

Office for Government Policy Coordination. (2016). 26th International Development Cooperation Committee: Meeting summary. Reports prepared by Office for Government Policy Coordination.

Office for Government Policy Coordination. (n/a). Multiple sources of South Korean aid. Retrieved April 12, 2021 from http://www. odakorea.go.kr.

O'Leary, R., \& Bingham, L. B. (2007). A manager's guide to resolving conflicts in collaborative networks. Center for the Business of Government.

Organisation for Economic Co-operation and Development-Development Assistance Committee (OECD, DAC). (1992). DAC principles for effective aid: Development assistance manual. OECD.

Organisation for Economic Co-operation and Development-Development Assistance Committee (OECD, DAC). (1996). Shaping the 21st Century: The Contribution of Development Co-operation. OECD.

Organisation for Economic Co-operation and Development - Development Assistance Committee (OECD/DAC). (2010). The Working Party on Aid Effectiveness - TransformingGlobal Partnerships for Development. Retrieved March 9, 2018 from http://www.oecd.org/dac/effectiveness/45498646.pdf.

Ostrom, E. (1990). Governing the commons: The evolution of institutions for collective action. Cambridge University Press.

O'Sullivan, R. G. (2012). Collaborative evaluation within a framework of stakeholder-oriented evaluation approaches. Evaluation and Program Planning, 35(4), 518-522.

Pfeiffer, J. (2003). International NGOs and primary health care in Mozambique: The need for a new model of collaboration. Social Science \& Medicine, 56(4), 725-738.

Pinto, J. K., \& Slevin, D. P. (1989). Critical success factors in R\&D projects. Research Technology Management, 32(1), 31-35.

Poole, D. L. (2008). Organizational networks of collaboration for community-based living. Nonprofit Management and Leadership, 18(3), 275-293.

Poulton, C., \& Macartney, J. (2012). Can public-private partnerships leverage private investment in agricultural value chains in Africa? A Preliminary Review. World Development, 40(1), 96-109.

Presser, S., \& Blair, J. (1994). Survey pretesting: Do different methods produce different results? Sociological Methodology, 24(2004), 73-104.

Provan, K. G., \& Kenis, P. (2008). Modes of network governance: Structure, management, and effectiveness. Journal of Public Administration Research and Theory, 18(2), 229-252.

Provan, K. G., \& Milward, H. B. (1995). A preliminary theory of interorganizational network effectiveness: A comparative study of four community mental health systems. Administrative Science Quarterly, 40(1), 1-33.

Provan, K. G., \& Milward, H. B. (2001). Do networks really work? A framework for evaluating public-sector organizational networks. Public Administration Review, 61(4), 414-423.

Raab, J., Mannak, R. S., \& Cambré, B. (2013). Combining structure, governance, and context: A configurational approach to network effectiveness. Journal of Public Administration Research and Theory, 25(2), 479-511.

Ragin, C. C. (1987). The comparative method: Moving beyond qualitative and quantitative strategies. University of California Press.

Ragin, C. C. (2000). Fuzzy-set social science. University of Chicago Press. 
Ragin, C. C. (2006). Set relations in social research: Evaluating their consistency and coverage. Political Analysis, 14(3), 291-310.

Ragin, C. C. (2008). Redesigning social inquiries. University of Chicago Press.

Ragin, C. C. (2009). Redesigning social inquiry: Fuzzy sets and beyond. University of Chicago Press.

Ring, P. S., \& Van de Ven, A. H. (1994). Developmental processes of cooperative interorganizational relationships. Academy of Management Review, 19(1), 90-118.

Rodriguez-Campos, L. (2012). Advances in collaborative evaluation. Evaluation and Program Planning, 35(4), 523-528.

Sakamoto, M. (2012). The rise of NGOs/NPOs in emergency relief in the great east Japan earthquake. Japan Social Innovation Journal, 2(1), 26-35.

Sandström, A., \& Carlsson, L. (2008). The performance of policy networks: The relation between network structure and network performance. Policy Studies Journal, 36(4), 497-524.

Schalk, J., Torenvlied, R., \& Allen, J. (2010). Network embeddedness and public agency performance: The strength of strong ties in Dutch higher education. Journal of Public Administration Research and Theory, 20(3), 629-653.

Schneider, C. Q., \& Wagemann, C. (2007). Qualitative Comparative Analysis (QCA) und Fuzzy-Sets: Ein Lehrbuch fur Anwender und jene, die es werden wollen. Verlag Barbara Budrich.

Schneider, C. Q., \& Wagemann, C. (2010). Qualitative comparative analysis (QCA) and fuzzy-sets: Agenda for a research approach and a data analysis technique. Comparative Sociology, 9(3), 376-396.

Schneider, C. Q., \& Wagemann, C. (2012). Set-theoretic methods for the social sciences: A guide to qualitative comparative analysis. Cambridge University Press.

Shin, W., Kim, Y., \& Sohn, H. (2017). Do different implementing partnerships lead to different project outcomes? Evidence from the World Bank project-level evaluation data. World Development, 95, 268-284.

Silvia, C. (2017). Picking the team: A preliminary experimental study of the activation of collaborative network members. Journal of Public Administration Research and Theory, 28(1), 120-137.

Singh, A., \& Prakash, G. (2010). Public-private partnerships in health services delivery: A network organizations perspective. Public Management Review, 12(6), 829-856.

Struyk, R. J. (2007). Factors in successful program implementation in Russia during the transition: Pilot programs as a guide. Public Administration and Development, 27(1), 63-83.
Taylor, H., Artman, E., \& Woelfer, J. P. (2012). Information technology project risk management: Bridging the gap between research and practice. Journal of Information Technology, 27(1), $17-34$.

Thomson, A. M. (2002). Collaboration: Meaning and measurement (Ph. D. dissertation). Indiana University.

Thomson, A. M., \& Perry, J. L. (2006). Collaboration processes: Inside the black box. Public Administration Review, 66(s1), 20-32.

Thomson, A. M., Perry, J. L., \& Miller, T. K. (2009). Conceptualizing and measuring collaboration. Journal of Public Administration Research and Theory, 19(1), 23-56.

Thorpe, J. (2018). Procedural justice in value chains through publicprivate partnerships. World Development, 103, 162-175.

Turrini, A., Cristofoli, D., Frosini, F., \& Nasi, G. (2010). Networking literature about determinants of network effectiveness. Public Administration, 88(2), 528-550.

Uster, A., Beeri, I., \& Vashdi, D. (2019). Don't push too hard. Examining the managerial behaviours of local authorities in collaborative networks with nonprofit organisations. Local Government Studies, 45(1), 124-145.

Wang, W. (2016). Exploring the determinants of network effectiveness: The case of neighborhood governance networks in Beijing. Journal of Public Administration Research and Theory, 26(2), $375-388$

Waugh, W. L., Jr. (2003). Terrorism, homeland security and the national emergency management network. Public Organization Review, 3(4), 373-385.

White, D., \& Fortune, J. (2002). Current practice in project management-an empirical study. International Journal of Project Management, 20(1), 1-11.

Willem, A., \& Lucidarme, S. (2014). Pitfalls and challenges for trust and effectiveness in collaborative networks. Public Management Review, 16(5), 733-760.

Wood, D. J., \& Gray, B. (1991). Toward a comprehensive theory of collaboration. Journal of Applied Behavioral Science, 27(2), 139-162.

Youker, R. (1999). Managing international development projectslessons learned. Project Management Journal, 30(2), 6-7.

Publisher's Note Springer Nature remains neutral with regard to jurisdictional claims in published maps and institutional affiliations. 